Research Article

\title{
Evolution Law of Coal Seam Abutment Pressure under the Influence of Shallow Buried Complex Strata: A Case Study
}

\author{
Buchu Zhang $\mathbb{D D}^{1,2}$ Dequan Sun, ${ }^{1,3}$ and Ruiliang Zheng ${ }^{4}$ \\ ${ }^{1}$ Engineering Laboratory of Deep Mine Rockburst Disaster Assessment in Shandong Province, \\ Shandong Coalfield Geology Bureau, Jinan 250100, China \\ ${ }^{2}$ State Key Laboratory of Mine Disaster Prevention and Control, Shandong University of Science and Technology, \\ Qingdao 266590, China \\ ${ }^{3}$ Shandong Institute of Coal Geological Planning and Investigation, Shandong Coalfield Geology Bureau, Jinan 250100, China \\ ${ }^{4}$ Shandong Xinjulong Energy Co., Ltd., Heze 274000, China
}

Correspondence should be addressed to Buchu Zhang; 525047249@qq.com

Received 27 December 2020; Revised 28 January 2021; Accepted 3 March 2021; Published 16 March 2021

Academic Editor: Giorgio Dalpiaz

Copyright (C) 2021 Buchu Zhang et al. This is an open access article distributed under the Creative Commons Attribution License, which permits unrestricted use, distribution, and reproduction in any medium, provided the original work is properly cited.

\begin{abstract}
The evolution law of lateral abutment pressure under the condition of fully mechanized mining in shallow coal seam is studied using the change process of coal pillar stress in disturbed section as the research object. The results of physical simulation experiment show that, after coal mining, due to the collapse of coal seam roof, the overlying strata of key layer will disturb the section coal pillar to different degrees, and the sudden change of degrees of abutment pressure near the coal wall reaches the maximum. Affected by the energy released by the fracture of key stratum, the stress mutation area shifts to the coal wall at a deeper level and the range of plastic zone increases. From the perspective of the numerical simulation, according to the change characteristics of coal pillar abutment pressure in the mining process, the dynamic load process of complex roof strata is divided into three stages: the stage not affected by mining, the stage of dynamic load action, and the stage of static load. In the first stage, the lateral abutment pressure is only affected by the roadway mining, causing stress concentration in the coal body. The stress concentration coefficient is small, and the supporting stress is stable. In the second stage, with the advance of the working face, the coal seam load changes continuously owing to the movement of overlying rock in the goaf, and the lateral abutment pressure changes evidently under the influence of dynamic load. In the third stage, the overlying load forms stress concentration in the coal seam and continuously transfers to the coal wall at a deeper level, which increases the limit equilibrium area of coal body. During this period, the range of plastic zone still increases at a certain rate for a period of time and finally tends to be stable.
\end{abstract}

\section{Introduction}

Xinjiang, Ordos Basin, and Eastern Inner Mongolia are the main coal energy production regions in China. There are a large number of shallow coalfields, buried underground within $150 \mathrm{~m}$. However, during the excavation of shallow coal seams, due to the influence of mining, the lateral abutment pressure in the stope is redistributed, and the overlying rock structure changes, leading to surface subsidence, bench subsidence, and other discontinuous deformation disasters. This seriously hinders the sustainable development of mine production. Therefore, it is important to master the dynamic evolution law of the lateral abutment pressure and to identify the structural change characteristics of overburden to control the surface discontinuous deformation.

Researchers at home and abroad have carried out a variety of researches regarding the change of overlying rock structure and the evolution law of abutment pressure of coal seam under the influence of mining. Frith and Reed [1] found that the overburden horizontal stress should be taken into account in the design pillars. Based on Corkum and Board [2], the significant mechanical difference between the overburden strata could easily lead to the formation of a stress arch in the overburden and then promote the occurrence of multilayer roof collapse accident. Sivakugan 
et al. [3] summarized two methods to solve the stress and analyzed the stress difference through a variety of research methods. Tian et al. [4] discovered that the abutment pressure of coal pillars doubled, the roof damage intensified, and the scope of overburden structure failure increased under the condition of multiseam mining. Chai et al. [5] carried out a research on the internal relationship between overburden structure and surface deformation in the mining process, controlled by the key strata of ultrathick conglomerate which was divided into three stages. Han et al. [6] established the key stratum shadow based on a physical simulation test. Ye et al. [7] found that large dip angles of coal seams result in uneven stress-increase zones of deep coal seams and frequent overlying rock separation phenomena. Under the condition of no or small pressure difference of overburden structure, Yang et al. [8] thought that the roof of the overburden rock is destroyed in the form of a composite beam. When the pressure difference of overburden structure is large, the roof will be bent. According to the horizontal and vertical stress distribution, Kong et al. [9] divided the arch areas into three parts, outer boundary, inner boundary, and centroid, and pointed out that the inner boundary is the main index to judge the stability of the roof. Wang et al. [10] found that, in shallow coal seam mining, there is a core load-bearing area in the pressure arch whose width determines the bearing capacity of the pressure arch. $\mathrm{Wu}$ et al. [11] think that the primary and periodic fractures of the key layer are caused by tensile failure. Song et al. [12] used structural mechanics and simulation tests to confirm that the increase of sandstone thickness can increase the overburden structure through the effective control of overburden strata in deep thick coal seam. Chen et al. [13] obtained the calculation formula and distribution law of the peak abutment pressure of coal pillars in a fully mechanized top-coal caving face by effective control of overlying strata in deep and thick coal seam. Jiang et al. [14] studied the surrounding rock control of roadway protection with different width pillars in a large section roadway of extrathick coal seam. Fu et al. [15] studied the roof fracture and lateral abutment pressure distribution law of thick coal seam and large mining height fully mechanized caving face. The overburden structure can be roughly divided into two categories: composite and noncomposite key overburden structures. Through summarizing the scholars' research results, it is found that the current researches mainly focus on noncomposite key stratum overburden structure, and some scholars [16-24] have studied the composite key stratum overburden structure of the main key and secondary key layers, which have achieved good results. However, the investigation of Yangjiacun coal mine reveals that the overburden structure of the mining area is special, and there are two subkey layers. Therefore, against the background of Yangjiacun coal mine as the engineering, through the methods of field investigation, theoretical analysis, numerical simulation experiment, and similar material simulation tests, this paper has carried out the study on the change of overburden structure and the lateral abutment pressure distribution law of the composite key layer of the main key layer + two secondary key layers in the mining process and the reasonable setting of coal pillar under the condition of overburden rock structure, which provides important guidance and reference.

\section{Research Conditions}

This study regards the 2201 mining face of Yangjiacun mine in the Inner Mongolia Autonomous Region as the research object. The coal seam in the working face belongs to 2-2 upper coal seam, the average dip angle of the coal seam is $1^{\circ}$ $15^{\prime}$, and its average thickness is $5.5 \mathrm{~m}$. The roof of the coal seam is fine sandstone and sandy mudstone, and the comprehensive column diagram of specific rock strata is shown in Table 1.

Yangjiacun coal mine has thick bedrock and thin loose layer on the surface. During the underground mining of Yangjiacun coal mine, the major findings were as follows: all the basic bedrock roofs collapsed behind; the overlying loose layer did not fall down completely; the roof structure was in dynamic change, which had a great impact on the evolution of lateral abutment pressure. In the process of coal mining, the roof strata of goaf have periodic fractures, and the fractured rock blocks are hinged to form an unstable "masonry beam" structure. The lateral abutment pressure changes significantly before and after the structural instability, which influences the roadway, as shown in Figure 1.

\section{Physical Simulation of Overburden Movement and Lateral Abutment Pressure Evolution}

\subsection{Scheme Design of Similar Simulation Test}

3.1.1. Selection of Similar Parameters and Model Laying. In this study, the overburden movement and the lateral abutment pressure evolution have been physically stimulated. Based on similarity theory and similar conditions, the similar material simulation test establishes a model similar to the geological structure and stress conditions on the field. The study later solved the problems of field observation difficulties and unclear mechanical structure. The similar condition parameters for similar material simulation were obtained by calculation, as shown in Table 2 .

The similar material simulation of shallow coal seam used the similar simulation test system of water inrush from mining coal seam floor, as shown in Figure 2. The parameters of the test bench are length $\times$ width $\times$ height $=900 \mathrm{~mm} \times 500 \mathrm{~mm} \times 800 \mathrm{~mm}$, and the model scale is $1: 200$. Sand, calcium carbonate, and gypsum were selected for the simulation test of similar materials, as shown in Figure 3. The sand was used as aggregate, and gypsum and calcium carbonate were used as bonding materials. In line with the geological conditions of the mine, the material erosion and layer thickness of each rock layer of the similar material model were calculated. The total thickness of the model was $662 \mathrm{~mm}$, according to the similarity ratio. The ratio of a similar material model is calculated in Table 3. 
TABLE 1: Comprehensive histogram of 2201 working face.

\begin{tabular}{|c|c|c|c|c|}
\hline Horizon & Rock name & $\begin{array}{c}\text { Layer } \\
\text { thickness }(\mathrm{m})\end{array}$ & $\begin{array}{l}\text { Cumulative } \\
\text { thickness }(\mathrm{m})\end{array}$ & Description \\
\hline 1 & Aeolian sand & 3.78 & 3.78 & $\begin{array}{l}\text { It is distributed in most of the well field, and its lithology is mainly } \\
\text { aeolian siltstone and fine sandstone }\end{array}$ \\
\hline 2 & Conglomerate & 40.26 & 44.04 & $\begin{array}{l}\text { The conglomerate is mainly composed of lithic debris with a small } \\
\text { amount of mineral debris }\end{array}$ \\
\hline 3 & Sandy mudstone & 12.50 & 56.54 & $\begin{array}{l}\text { It has mixed colors including purplish red, mica and high clay } \\
\text { content, and shell-like fracture }\end{array}$ \\
\hline 4 & $\begin{array}{l}\text { Medium grained } \\
\text { sandstone }\end{array}$ & 22.03 & 78.57 & $\begin{array}{l}\text { It is grayish green, containing mica and locally feldspar. It is generally } \\
\text { sorted and argillaceous cemented }\end{array}$ \\
\hline 5 & Mudstone & 5.12 & 83.69 & $\begin{array}{c}\text { It is gray black and has an argillaceous structure and relatively flat } \\
\text { fracture }\end{array}$ \\
\hline 6 & Sandy mudstone & 3.47 & 87.16 & $\begin{array}{c}\text { It is grayish black and medium thick layered, has an argillaceous } \\
\text { structure, and is hard }\end{array}$ \\
\hline 7 & $\begin{array}{l}\text { Fine grained } \\
\text { sandstone }\end{array}$ & 14.48 & 101.64 & It is light gray, thick layered, dense, and hard \\
\hline 8 & Mudstone & 8.5 & 110.14 & $\begin{array}{c}\text { It is gray black and thin layered, has an argillaceous structure, is of } \\
\text { hard quality, and has a complete core }\end{array}$ \\
\hline 9 & Sandy mudstone & 4.55 & 114.69 & $\begin{array}{c}\text { It is gray dark gray, massive, and containing carbon chips and sliding } \\
\text { surface and has a flat fracture surface }\end{array}$ \\
\hline 10 & $2-2$ coal & 5.50 & 120.19 & $\begin{array}{l}\text { It is black, massive, dark coal, containing silky carbon and dull luster, } \\
\text { and locally containing a small amount of mudstone }\end{array}$ \\
\hline 11 & Sandy mudstone & 4.03 & 124.22 & $\begin{array}{c}\text { It is gray black and thin layered and has an argillaceous structure and } \\
\text { a relatively flat fracture }\end{array}$ \\
\hline 12 & $\begin{array}{l}\text { Fine grained } \\
\text { sandstone }\end{array}$ & 8.15 & 132.37 & $\begin{array}{l}\text { It is light gray and thick layered, has fine grained sand-like structure, } \\
\text { is hard, is mainly composed of felsic, and is followed by dark } \\
\text { minerals, with more carbonaceous stripes }\end{array}$ \\
\hline
\end{tabular}

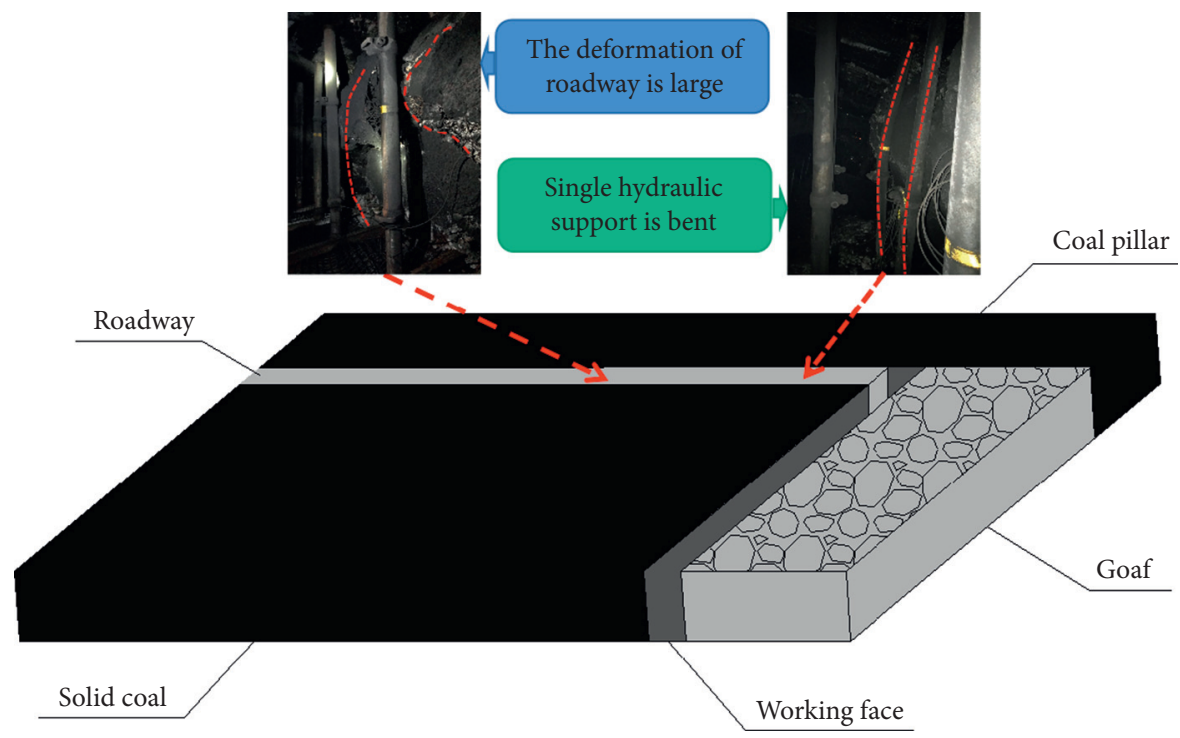

FIGURE 1: Working face site conditions.

3.1.2. Monitoring Scheme Design. In order to study the characteristics of overburden movement and lateral abutment pressure evolution during coal seam excavation, it was necessary to arrange a number of measuring points in the coal seam and overlying strata to monitor the stress evolution process. Four groups of measuring lines (Figure 4(a)) were arranged in the coal seam, with a distance of $5 \mathrm{~cm}$ between each of the four groups. There were 4 measuring points in each group, and the distance between adjacent measuring points was $6 \mathrm{~cm}$. The measuring points of two adjacent groups of measuring lines were staggered. The distance between the first group of measuring lines and the third group of measuring lines was 15 and $55 \mathrm{~cm}$, respectively. Three groups of measuring lines (Figure $4(\mathrm{~b})$ ) were arranged at $10 \mathrm{~cm}$ above the coal seam; the measuring lines 5,6 , and 7 were, respectively, 
TABLE 2: Model design parameters.

\begin{tabular}{lc}
\hline Project & Parameter \\
\hline Model scale & $1: 200$ \\
Model length/mm & 900 \\
Model width/mm & 500 \\
Model height/mm & 800 \\
Simulation method & Fully mechanized mining \\
Time similarity & $1 / 10$ \\
Bulk density similarity & $1 / 1.5$ \\
Strength similarity & $1 / 300$ \\
External force similarity & $1 / 300$ \\
Simulation similarity & Inclination \\
\hline
\end{tabular}

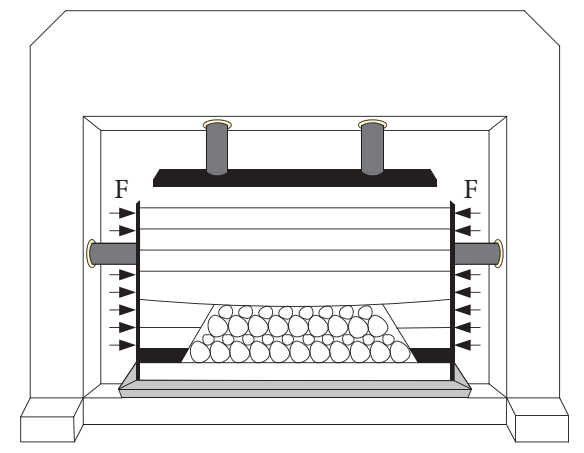

(a)

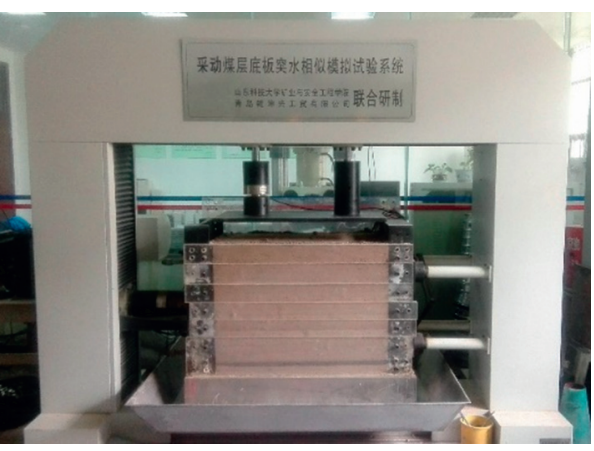

(b)

FIgURE 2: Schematic diagram of the model. (a) Similar simulation test system. (b) Schematic diagram of model stress simulation.
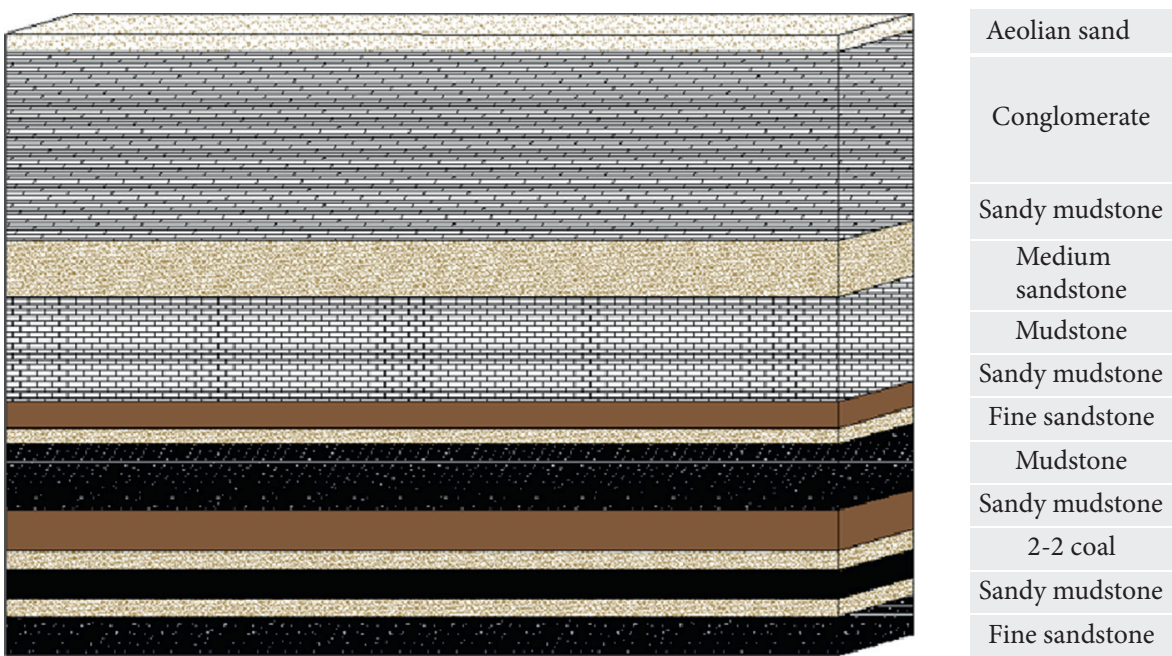

FIGURE 3: Schematic diagram of similar material simulation.

above the measuring lines 1, 2, and 3; and the distance between measuring points of each group of measuring lines was $6 \mathrm{~cm}$. The specific location of measuring points is shown in Figure 4.

\subsection{Analysis of Similar Simulation Test Results}

3.2.1. Movement Analysis of Similar Material Overburden. The length of the simulated working face was $60 \mathrm{~m}$; the measuring points were arranged within $40 \mathrm{~m}$ of the lateral coal body; and the working face advanced along the coal seam trend. The simulation excavation time ratio was $1: 10$; the excavation was conducted once every $2 \mathrm{~h}$; and each excavation was $5 \mathrm{~cm}$. During the excavation process, the first weighting and periodic weighting steps of the working face were observed and recorded. In addition, the key processes such as deformation, fracture, and collapse of the key overburden layer were recorded, as shown in Figure 5.

It can be seen from Figure 5 that the roof of coal seam had no obvious change in the process of $50 \mathrm{~m}$ advancing of 
TABLE 3: Material ratio of the model rock layer.

\begin{tabular}{|c|c|c|c|c|c|c|c|c|c|}
\hline \multirow[b]{2}{*}{ Lithology } & \multirow[b]{2}{*}{$\begin{array}{l}\text { Thickness of } \\
\text { protolith (m) }\end{array}$} & \multirow[b]{2}{*}{$\begin{array}{l}\text { Model delamination } \\
\text { thickness }(\mathrm{mm})\end{array}$} & \multirow[b]{2}{*}{$\begin{array}{l}\text { Matching } \\
\text { number }\end{array}$} & \multirow{2}{*}{$\begin{array}{c}\text { Bulk } \\
\text { density }(\mathrm{g} / \\
\left.\mathrm{cm}^{3}\right)\end{array}$} & \multirow[b]{2}{*}{$\begin{array}{l}\text { Weight } \\
(\mathrm{kg})\end{array}$} & \multicolumn{4}{|c|}{ Material consumption per layer $(\mathrm{kg})$} \\
\hline & & & & & & Sand & $\begin{array}{l}\text { Calcium } \\
\text { carbonate }\end{array}$ & Gypsum & Water \\
\hline Aeolian sand & 3.78 & 19 & $05: 01$ & 1.08 & 10.15 & 10.15 & $\begin{array}{c}\text { Sawdust } \\
1.54\end{array}$ & 1.05 & \\
\hline Conglomerate & 40.26 & 200 & $7: 5: 5$ & 1.6 & 182.2 & 159.4 & 11.4 & 11.39 & 18.2 \\
\hline Sandy mudstone & 12.50 & 63 & $8: 6: 4$ & 1.5 & 46.8 & 41.6 & 3.1 & 2.08 & 4.7 \\
\hline $\begin{array}{l}\text { Medium grained } \\
\text { sandstone }\end{array}$ & 22.03 & 110 & $7: 7: 3$ & 1.6 & 87.1 & 76.2 & 7.6 & 3.27 & 8.7 \\
\hline Mudstone & 5.12 & 26 & $8: 6: 4$ & 1.5 & 12.6 & 11.2 & 0.84 & 0.56 & 1.3 \\
\hline Sandy mudstone & 3.47 & 18 & $8: 6: 4$ & 1.5 & 5.2 & 4.6 & 0.35 & 0.23 & 0.52 \\
\hline $\begin{array}{l}\text { Fine grained } \\
\text { sandstone }\end{array}$ & 14.48 & 72 & $7: 8: 2$ & 1.6 & 23 & 20.1 & 2.3 & 0.57 & 2.3 \\
\hline Mudstone & 8.5 & 42 & $8: 6: 4$ & 1.5 & 6.7 & 6 & 0.45 & 0.3 & 0.67 \\
\hline Sandy mudstone & 4.55 & 23 & $8: 6: 4$ & 1.5 & 6.7 & 6 & 0.45 & 0.3 & 0.67 \\
\hline $2-2$ coal & 5.5 & 28 & $8: 6: 4$ & 1.35 & 17.4 & 15 & 1.16 & 0.77 & 1.74 \\
\hline Sandy mudstone & 4.03 & 20 & $8: 6: 4$ & 1.5 & 5.2 & 4.6 & 0.35 & 0.23 & 0.52 \\
\hline $\begin{array}{l}\text { Fine grained } \\
\text { sandstone }\end{array}$ & 8.15 & 41 & $7: 8: 2$ & 1.6 & 33.3 & 29.1 & 3.32 & 0.84 & 3.3 \\
\hline All & 132.37 & 662 & & & 517.96 & 456.35 & 38 & 23.6 & 52 \\
\hline
\end{tabular}

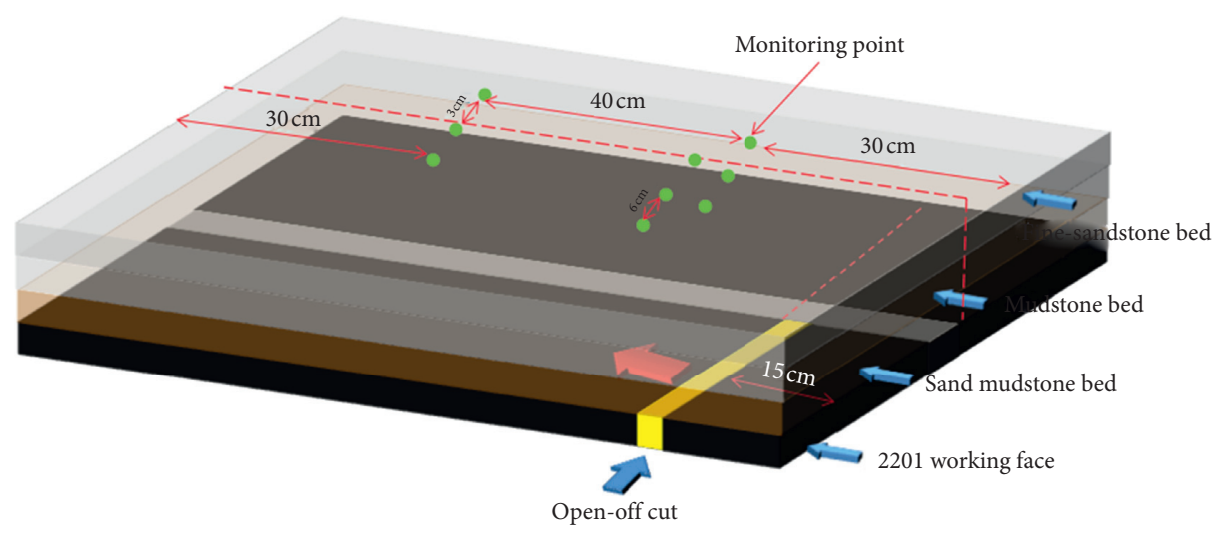

(a)

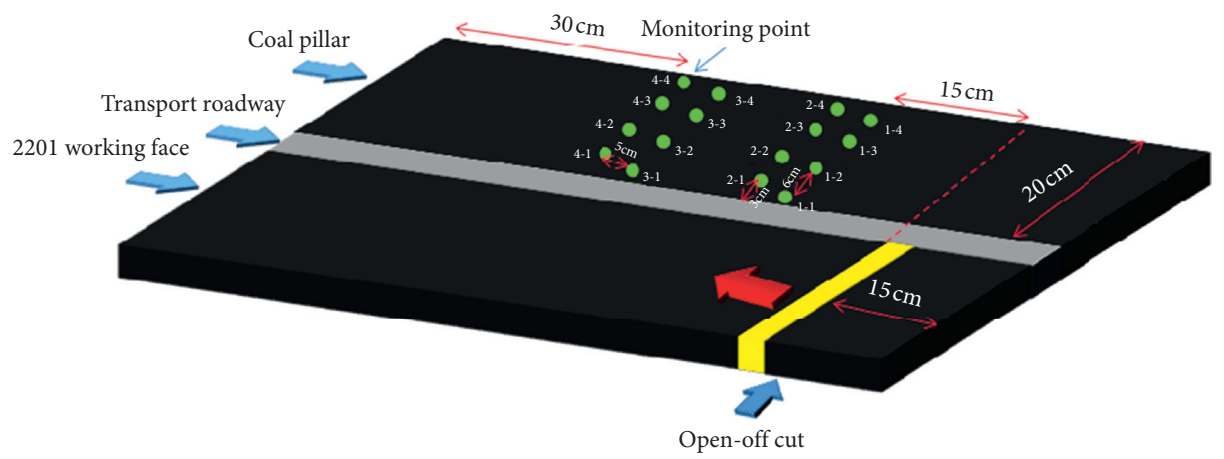

(b)

FIgURE 4: Layout of measuring points for similar material simulation.

the working face (Figure 5(a)); however, when the advancing distance of the working face reached $50 \mathrm{~m}$, obvious bending and sinking of the direct roof occurred, and local collapse and fracture zone appeared behind the working face (Figure 5(b)); when the working face was mined to $70 \mathrm{~m}$, the rotary deformation of the rock mass above the open-off cut was in the form of a hinge joint, and the direct roof behind the working face collapsed completely; when the working face advanced to $80 \mathrm{~m}$, the overlying strata in the goaf collapsed in a large area. At the same time, the subkey stratum collapsed due to the large hanging roof area. At that time, the caving height was $27.5 \mathrm{~m}$ (Figure 5(e)). According 


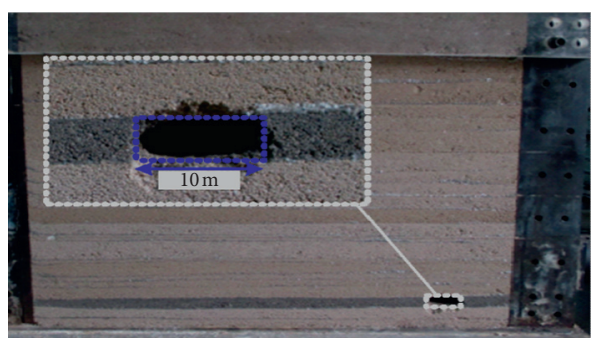

(a)

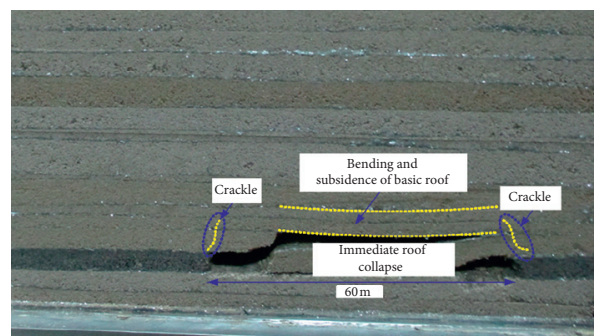

(c)

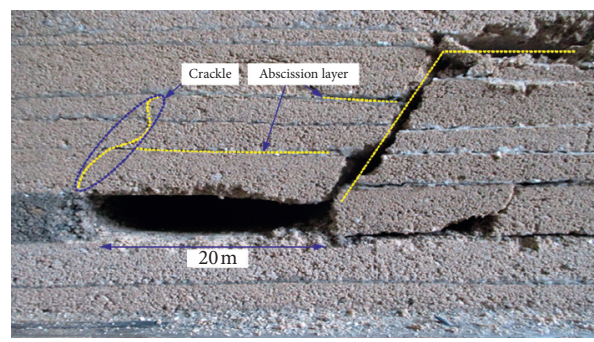

(e)

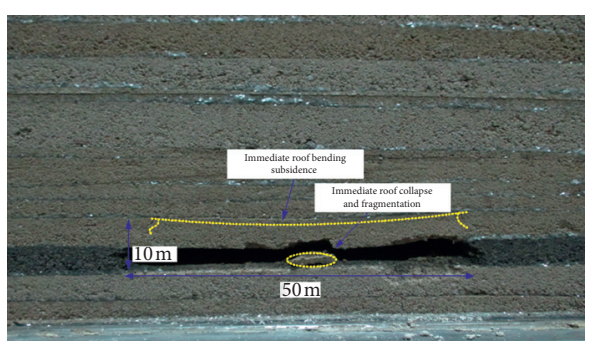

(b)

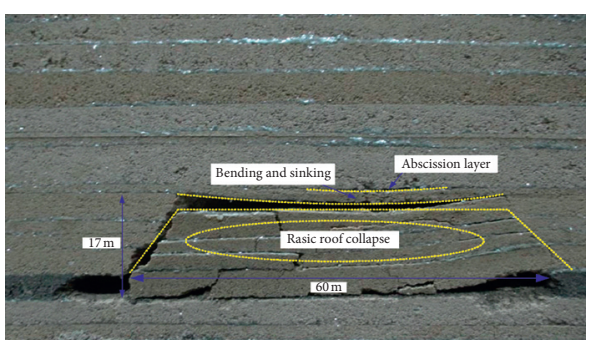

(d)

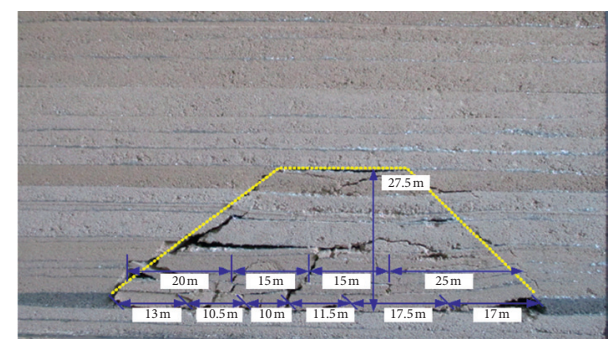

(f)

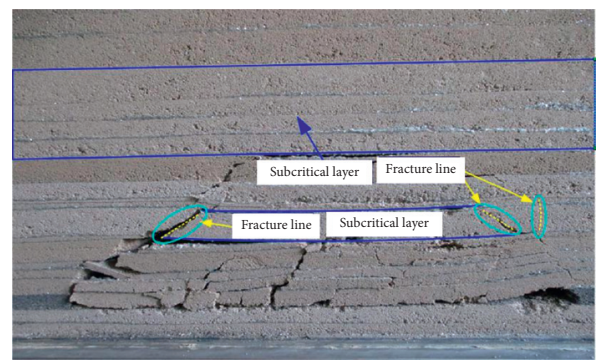

(g)

FIGURE 5: Overlying strata movement in seam mining. (a) Working face advancing $10 \mathrm{~m}$. (b) Working face advancing $50 \mathrm{~m}$. (c) Working face advancing $60 \mathrm{~m}$. (d) Working face advancing $70 \mathrm{~m}$. (e) Working face advancing $80 \mathrm{~m}$. (f) Stability of overlying strata after working face advancing for $80 \mathrm{~m}$. (g) Schematic diagram of the key layer above working face.

to the way the strata broke, the overlying strata in the goaf would collapse in a large area. It was found through the whole mining process that the strata above the open-off cut are articulated, which did not change with the advance of the working face. However, the overburden behind the working face showed an unstable hinged structure, which is prone to rock instability and overall cutting subsidence.

\subsubsection{Analysis of Structural Evolution and Stress Transfer} Law of Key Layer. The overlying strata of the Yangjiacun coal mine are a composite key layer structure. When the working face is mined, coal pillars and roadway surrounding rock are affected by dynamic load disturbance of varying degrees, such as rock fracture and collapse and fault sliding. This dynamic load disturbance phenomenon has an important impact on the safety operation of a coal mine. Under the action of mine pressure, the key stratum is broken and unstable, releasing energy externally, and causing coal body damage and response. The redistribution of forces is an important source of dynamic load disturbance in coal mines. There are many factors of coal mine dynamic load disturbances, such as fault sliding, drilling and blasting, and earthquake, and other geological phenomena can produce dynamic loads. However, affected by experimental conditions, this study only focuses on the dynamic load phenomenon of key stratum fracture and collapse. The dynamic load caused by roof fracture is shown in Figure 6. 


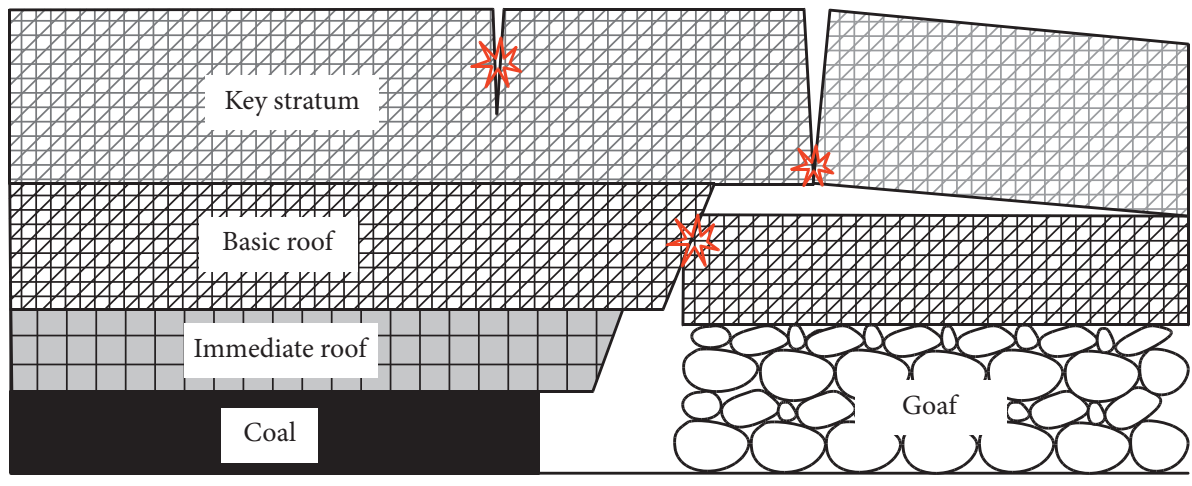

FIgURE 6: Sketch of dynamic load produced by roof fracture.

During the coal seam excavation, the movement of the key layer and the monitoring stress have been observed at the same time. At the end of the experiment, the fracture of the key layer is combined with the stress change of the measuring point, and the stress evolution has been compared and analyzed, as shown in Figure 7.

As shown in Figure 7(a), the stress evolution trend of measuring point $2-1$ is different from that of measuring point 5-2. The stress of measuring point 2-1 increases with the advance of working face, and the stress evolution curve of measuring point 5-2 first increases and then decreases with the advance of working face. By analyzing the stress evolution curve, it can be concluded that measuring point 5-2 is located outside the fracture line of key stratum, and the stress decreases greatly due to the fracture instability of the key stratum; during this period, the stress of key stratum decreases under the influence of the gravity of the overlying strata in the goaf and the stress of measuring point 2-1 increases significantly at the corresponding time. It can be seen from Figure 7(b) that the trends of the stress evolution curves of measuring points 2-2 and 6-1 are the same. In addition, the stress of the two measuring points is affected by the breaking and instability disturbance of key stratum, and both of them show an upward trend with the excavation of the working face. It can be seen from Figures 7(c) and 7(d) that the two measuring points are horizontally far away from the lateral coal wall, so the dynamic load disturbance has little influence on the stress fluctuation. When the working face is close, due to the influence of advanced abutment pressure and fracture instability of key stratum, the stress evolution increases greatly.

A large amount of energy is released from the fracture failure of the key layer, and the lateral coal body redistributes the stress. The dynamic load disturbance causes the peak stress of the lateral coal body to increase, and the peak stress shifts to the coal wall at the deep level. The stress drops outside the fault line and is lower than the original rock stress. Due to the disturbance, the range of the lateral coal plastic zone also increases, as shown in Figure 8 .

\section{Numerical Simulation of Lateral Pressure Evolution of Coal Mass}

\subsection{Design of Numerical Model for Stress Evolution and Excavation Scheme}

4.1.1. 3D Numerical Model Creation. In order to study the evolution characteristics of lateral abutment pressure in coal mining, a FLAC3D numerical calculation model was established. According to the geological conditions and mining site of the Yangjiacun coal mine, the dip length ( $X$ direction) is $120 \mathrm{~m}$; the strike length ( $Y$ direction) is $250 \mathrm{~m}$; and the height ( $Z$ direction) is $45 \mathrm{~m}$. In order to simplify the calculation, a certain height of the roof and floor of the coal seam was selected for the numerical simulation calculation model. As shown in Figure 9, among the coal seam roof, sandy mudstone thickness is $5 \mathrm{~m}$, mudstone thickness is $8.5 \mathrm{~m}$, and fine sandstone thickness is $15 \mathrm{~m}$. As for coal floor, sandy mudstone thickness is $4 \mathrm{~m}$, fine sandstone thickness is $8 \mathrm{~m}$, coal seam thickness is $5.5 \mathrm{~m}$, coal seam dip angle is $0^{\circ} 30^{\prime}-2^{\circ}$, and the average is $1^{\circ} 15^{\prime}$ in a horizontal state.

4.1.2. Parameter Selection. The plastic softening model and viscoelastic plastic model were used to simulate the coal seam excavation and rheological process. The boundary conditions of the model were set according to the top loading, and the other five edges were constrained by the interface to fix the displacement in $X, Y$, and $Z$ directions. According to the geological conditions, the burial depth of the coal seam was $120 \mathrm{~m}$, and the stress of the coal seam under the original rock stress is $3.9 \mathrm{MPa}$. In order to simplify the simulation, the height, length, and width of the model were 45,250 , and $120 \mathrm{~m}$, respectively. See Table 4 for the parameters of each rock stratum of the model.

4.1.3. Simulation Scheme Design. The width of simulated coal seam excavation was $60 \mathrm{~m}$, with each time the model being excavated $20 \mathrm{~m}$. In addition, the operation steps 


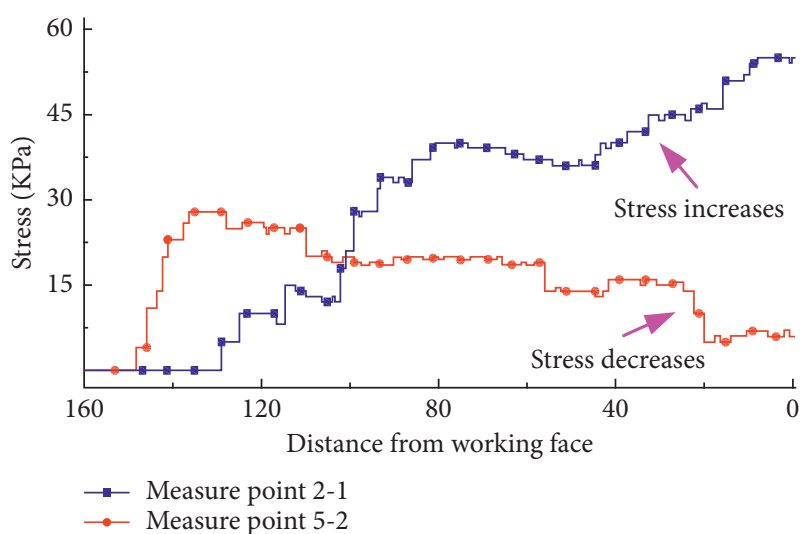

(a)

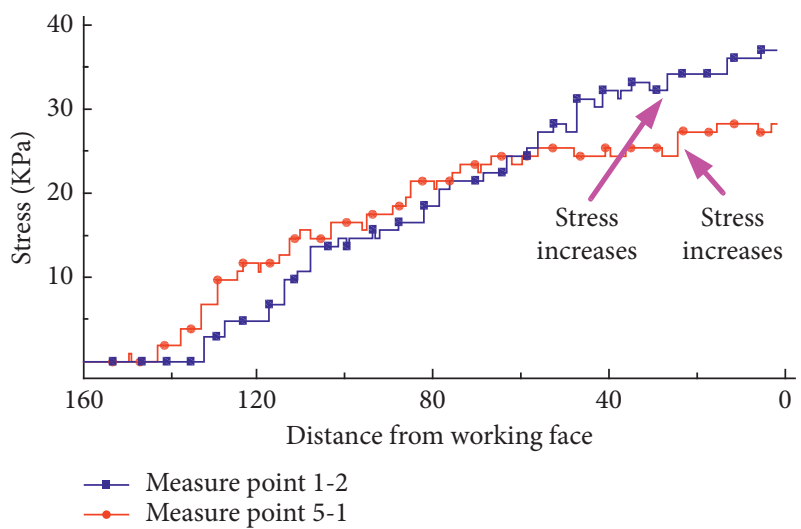

(c)

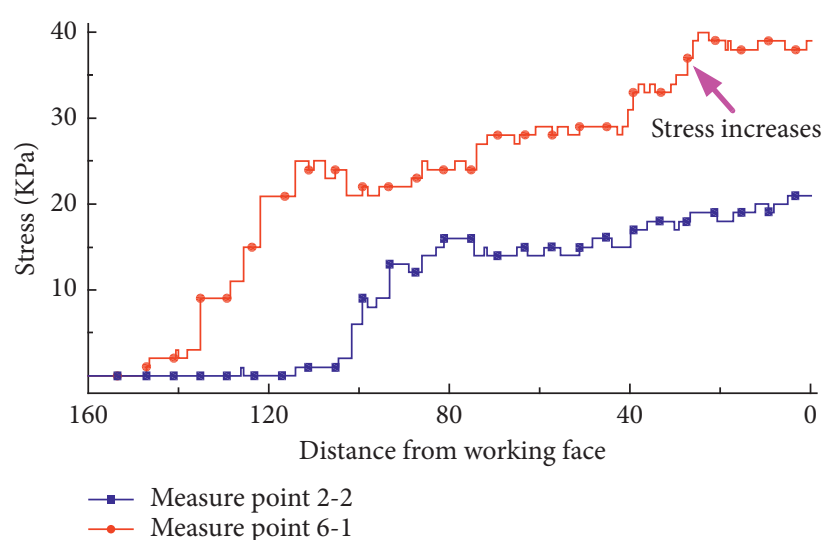

(b)

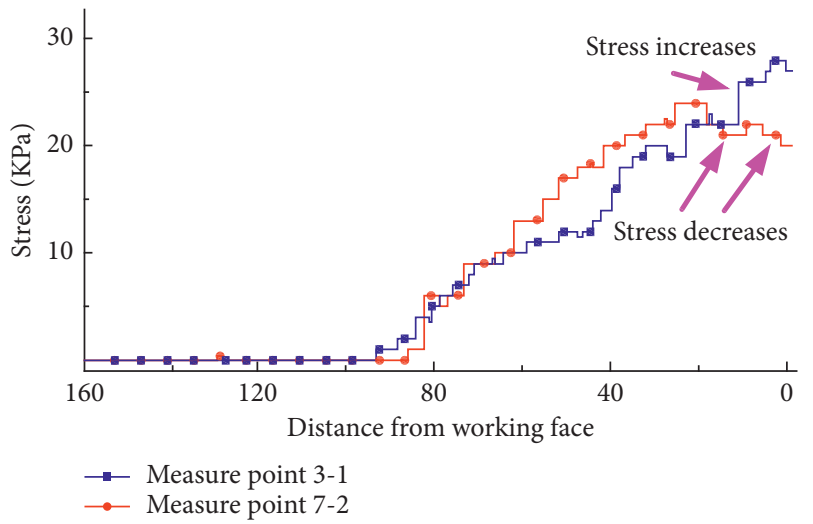

(d)

FiguRE 7: Stress evolution contrast analysis diagram of different measuring points. (a) Stress evolution curves of measuring points 2-1 and 52. (b) Stress evolution curve of measuring points 2-2 and 6-1. (c) Stress evolution curve of measuring point 1-2 and 5-1. (d) Stress evolution curve of measuring points 3-1 and 7-2.

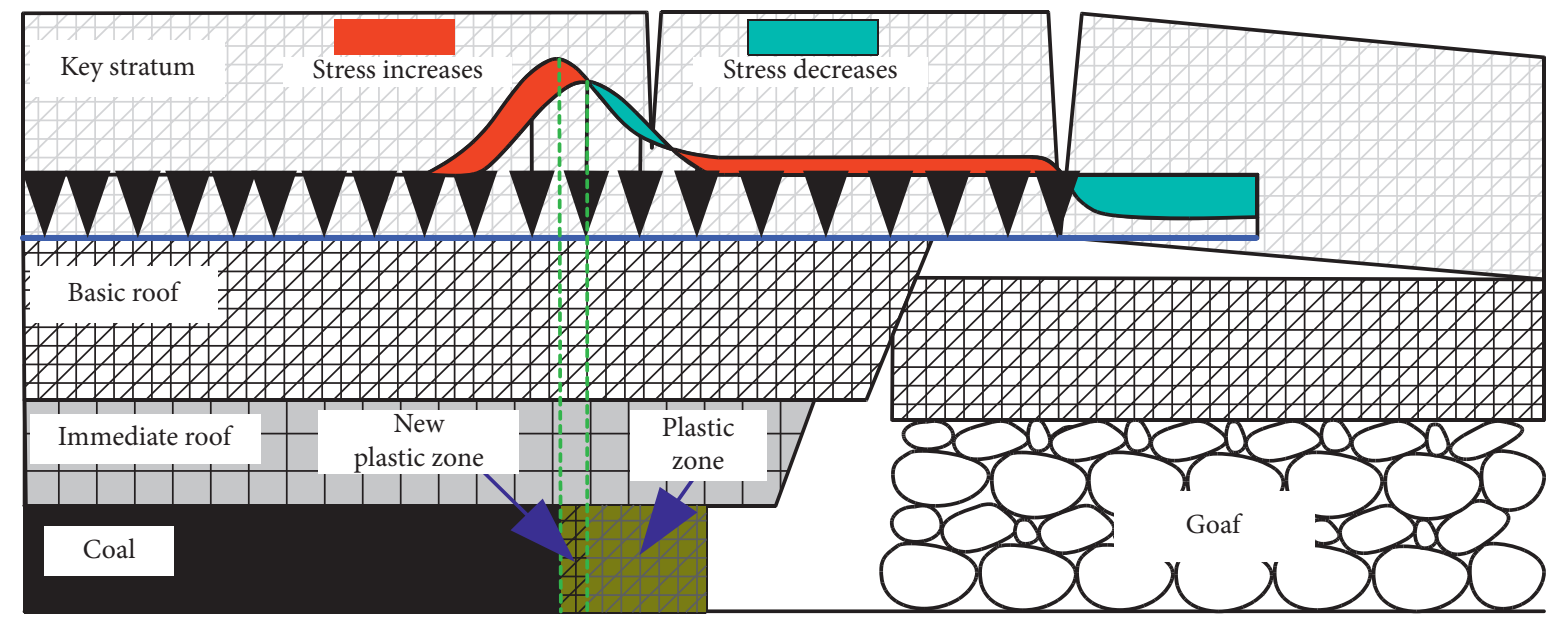

FIGURE 8: Stress and plastic zone change of surrounding rock under dynamic loading.

were 2000 steps; then the excavation was $20 \mathrm{~m}$ and the working face length was $220 \mathrm{~m}$. In the process of model excavation, the range of lateral coal plastic zone, the peak value of lateral pressure stress, the range of limit equilibrium zone, the influence range of stress, and the equilibrium time of the model were monitored in real time. After the model was balanced, the plastic softening model was regarded as the viscoelastic plastic model, and the stress evolution characteristics in the rheological state were further studied. 


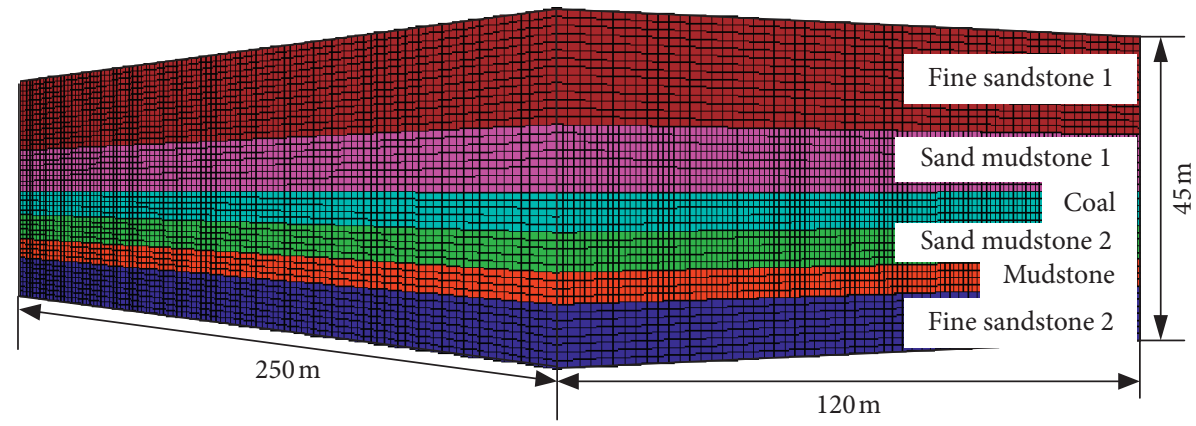

FIgURE 9: Numerical model.

TABLE 4: Mechanical parameters of rock formation.

\begin{tabular}{|c|c|c|c|c|c|c|c|c|}
\hline Category & Lithology & $\begin{array}{c}\text { Thickness } \\
(\mathrm{m})\end{array}$ & $\begin{array}{c}\text { Bulk modulus } \\
(\mathrm{GPa})\end{array}$ & $\begin{array}{c}\text { Shear } \\
\text { modulus }\end{array}$ & $\begin{array}{l}\text { Density } \\
(\mathrm{kg} / \mathrm{m} 3)\end{array}$ & $\begin{array}{c}\text { Internal friction } \\
\text { angle }(\circ)\end{array}$ & $\begin{array}{c}\text { Cohesion } \\
(\mathrm{MPa})\end{array}$ & $\begin{array}{c}\text { Tensile strength } \\
(\mathrm{MPa})\end{array}$ \\
\hline \multirow{3}{*}{ Roof } & $\begin{array}{l}\text { Fine grained } \\
\text { sandstone }\end{array}$ & 15 & 5.67 & 3.05 & 2560 & 28 & 2.7 & 5.1 \\
\hline & Mudstone & 8.5 & 2.8 & 1.26 & 2080 & 30 & 2.8 & 1.2 \\
\hline & Sandy mudstone & 5 & 3.16 & 2.46 & 2380 & 31 & 3.0 & 3.0 \\
\hline $\begin{array}{l}\text { Coal } \\
\text { seam }\end{array}$ & $2-2$ coal & 5.5 & 1.4 & 0.54 & 1400 & 32 & 1.0 & 0.7 \\
\hline \multirow[b]{2}{*}{ Floor } & Sandy mudstone & 5 & 3.16 & 2.46 & 2380 & 31 & 3.0 & 3.0 \\
\hline & $\begin{array}{l}\text { Fine grained } \\
\text { sandstone }\end{array}$ & 8 & 5.67 & 3.05 & 2560 & 28 & 2.7 & 5.1 \\
\hline
\end{tabular}

\subsection{Analysis of Simulation Results}

4.2.1. Evolution and Transfer Law of Lateral Coal Stress under Dynamic Load (Excavation Process). During the period of the excavation of the working face up to the movement balance of the overlying strata in the goaf, the measuring points were set up in the lateral coal body $50 \mathrm{~m}$ in front of the working face to monitor the stress changes of the lateral coal body. Each excavation was $20 \mathrm{~m}$. After the excavation, the corresponding stress distribution nephogram is obtained, as shown in Figure 10.

In order to study the evolution of lateral abutment pressure in a dynamic loading stage, the evolution of the peak value of the lateral abutment pressure and the range of the plastic zone from coal seam excavation up to model equilibrium were simulated and are shown in Figure 11.

It can be seen from Figure 11 that the evolution of the lateral abutment pressure is divided into four stages: advanced abutment pressure influence stage, stress rising stage, peak stress, and peak stress maintenance stage. Before $30 \mathrm{~m}$, the lateral abutment pressure is only affected by roadway excavation, which is higher than the original rock stress of the coal seam. At that stage, the coal body is not affected by the advanced abutment pressure, and the abutment pressure changes slowly. The $-30-0 \mathrm{~m}$ section of the working face is affected by the advanced abutment pressure, the stress in that stage is affected by the roadway excavation stress concentration and the advanced abutment pressure, and the abutment pressure curve rises in an upward concave shape. The $0-60 \mathrm{~m}$ section is the stage of stress rise. In that stage, the overhanging area of overlying strata in goaf increases greatly, which results in the stress times of the coal body, and the curve of abutment pressure increases approximately in a straight line. When the working face goes over $80 \mathrm{~m}$, the movement of strata in goaf tends to be progressively stable and gradually enters the peak stress stage. The stress begins to decrease slowly and tends to be stable.

4.2.2. Stress Evolution and Transfer Law of Lateral Coal Mass under Static Load (after Excavation Stability). In coal mining, after the overlying strata are stable, the coal seam remained unchanged for a long time under the action of selfweight load and tectonic stress. This state can be regarded as a static load of coal body. In order to study the evolution of abutment pressure of lateral coal body and the characteristics of coal rock failure under this condition, the equilibrium model is adopted and its constitutive relation is changed to study the characteristics of stress intensity of coal body in a rheological state.

The rheological model is a kind of model that can simulate the complex deformation of materials. The typical viscoelastic model (the so-called burger) cannot effectively describe the whole process of rock creep. Therefore, the Mohr-Coulomb model and the viscoelastic model (burger) are connected to establish the corresponding series model of the viscoelastic model (burger) and the Mohr-Coulomb model (M-C), namely, the cvisc model, as shown in Figure 12. Types of parameters are shown in Table 5.

As shown in Figure 12, in order to facilitate the representation, the element symbols are simplified, and $E$ is 


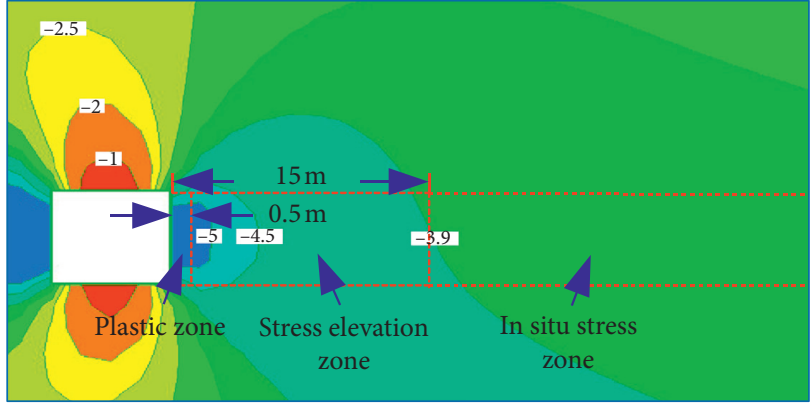

(a)

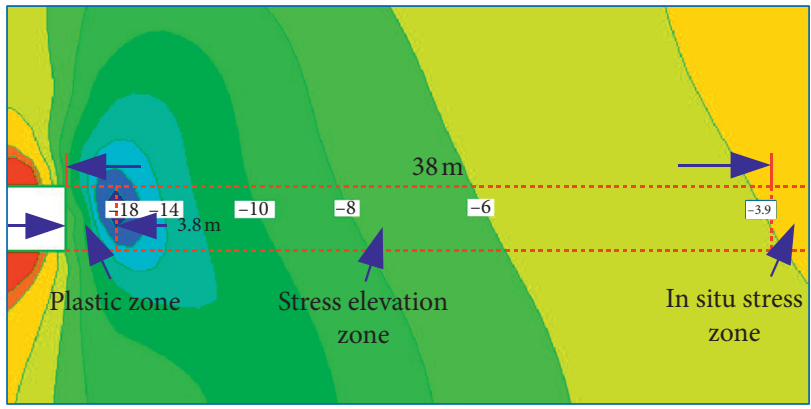

(c)

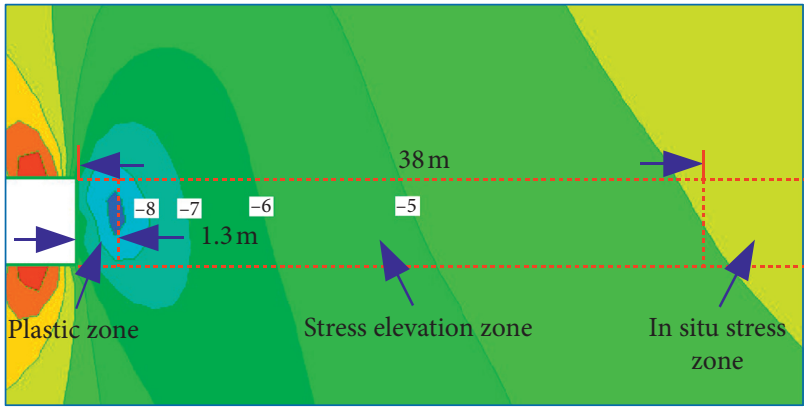

(b)

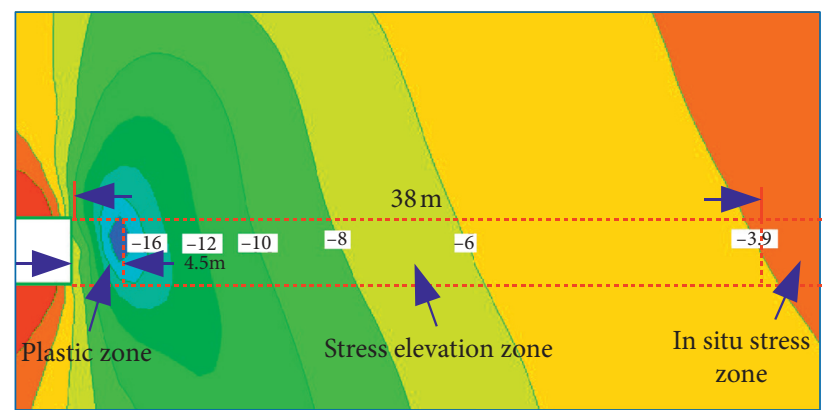

(d)

Figure 10: Vertical stress distribution of lateral coal. (a) $-30 \mathrm{~m}$ stress distribution nephogram (note: $-30 \mathrm{~m}$ is $30 \mathrm{~m}$ in front of the initial measuring point). (b) Nephogram of stress distribution at open cut. (c) $40 \mathrm{~m}$ stress distribution nephogram (note: $40 \mathrm{~m}$ is $40 \mathrm{~m}$ behind the initial measuring point). (d) Stress distribution nephogram of $80 \mathrm{~m}$ (note: $80 \mathrm{~m}$ is $80 \mathrm{~m}$ behind the initial measuring point).

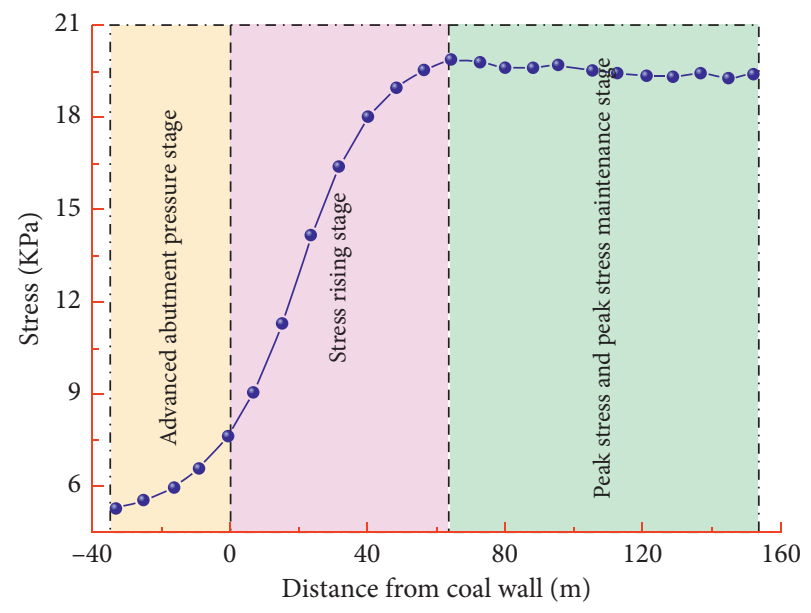

FIGURE 11: Lateral abutment pressure evolution curve.

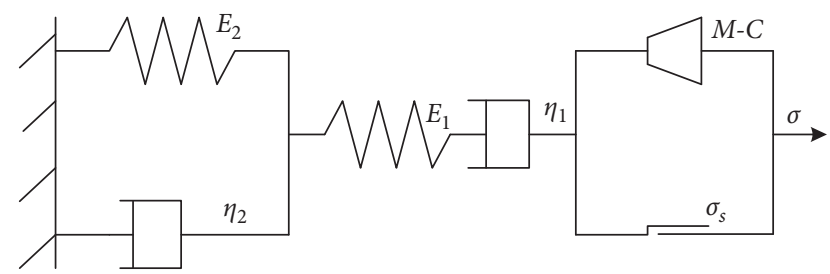

FIGURE 12: Viscoelastic model. represented as an elastic body and a viscous body. If $\sigma<\sigma_{S}$, the constitutive model is the burger model, and its rheological constitutive model is the burger model creep:

$$
\sigma+\left(\frac{\eta_{1}}{E_{1}}+\frac{\eta_{2}}{E_{2}}+\frac{\eta_{1}}{E_{2}}\right) \dot{\sigma}+\frac{\eta_{1} \eta_{2}}{E_{1} E_{2}}=\eta_{1} \dot{\varepsilon}+\frac{\eta_{1} \eta_{2}}{E_{2}} \ddot{\varepsilon}
$$

If $\sigma \geq \sigma_{s}$, the cvisc model can be expressed as follows:

$$
\varepsilon=\frac{\sigma}{E_{1}}+\frac{\sigma}{\eta_{1}} t+\frac{\sigma}{E_{2}}\left[1-e^{-\left(e_{2} / \eta_{2}\right) t}\right]+\varepsilon^{p},
$$

where $\varepsilon^{p}$ is the plastic strain and $\sigma_{s}$ is the material yield limit total strain rate:

$$
\begin{gathered}
\text { total strain rate }: \dot{e}_{i j}=\dot{e}_{i j}^{k}+\dot{e}_{i j}^{m}+\dot{e}_{i j}^{p}, \\
\text { Kelvin }: s_{i j}=2 \eta_{2} \dot{e}_{i j}^{k}+2 E_{2} e_{i j}, \\
\text { Maxwell }: \dot{e}_{i j}^{m}=\frac{\dot{s}_{i j}}{2 E_{1}}+\frac{s_{i j}}{2 \eta_{1}}, \\
\mathrm{M}-\text { C original }: \dot{e}_{i j}^{p}=\lambda \frac{\partial g}{\partial \sigma_{i j}}-\frac{1}{3} \dot{e}_{\mathrm{vol}}^{p} \delta_{i j} .
\end{gathered}
$$

$\mathrm{M}-\mathrm{C}$ yield criterion and shear yield criterion in the form of stress invariant are as follows:

$$
F=\sigma_{m} \sin (\varphi)+\bar{\sigma} K(\theta)-c \cos (\varphi),
$$


TABle 5: Rheological model parameters.

\begin{tabular}{lcccc}
\hline & \multicolumn{2}{c}{ Elastic modulus (MPa) } & \multicolumn{2}{c}{$\begin{array}{c}\text { Viscosity coefficient }(109 \\
(\mathrm{Pa} / \text { year) }\end{array}$} \\
Parameter & $\begin{array}{c}\mathrm{M} \text { model } \\
\left(E_{1}\right)\end{array}$ & $\mathrm{K}$ model & $\mathrm{M}$ model & $\mathrm{K}$ model \\
$\left(E_{2}\right)$ & $\left(\eta_{1}\right)$ & $\left(\eta_{2}\right)$ \\
\hline Value & 2536.9 & 6410.8 & 37.0 & 11.3 \\
\hline
\end{tabular}

where $\mathrm{C}$ is the cohesion; $\varphi$ is the internal friction angle; $\sigma \mathrm{m}$ is the average stress, $\sigma_{m}=I_{1} / 3 ; \bar{\sigma}$ is the equivalent stress, $\bar{\sigma}=\sqrt{I_{2}} ; \mathrm{I} 1$ is the first invariant of stress; I 2 is the second invariant of stress; $\theta$ is the lode angle, $K(\theta)=\cos (\theta)-(1 / \sqrt{3}) \sin (\varphi) \cos (\varphi)$.

The tensile yield criterion expressed by the stress invariant is

$$
F=\frac{2}{3} \bar{\sigma} \sin \left(\theta+120^{\circ}\right)+\sigma_{m}-f_{c} .
$$

$\mathrm{Fc}$ is the tensile strength of a rock medium.

After the coal seam is excavated until the overlying rock movement stops and the model is balanced, the coal seam remains unchanged for a long time under the action of selfweight load and the tectonic stress. This state reveals that when the coal body is under the action of static load, the coal body enters into a rheological state. In order to study the evolution law of lateral stress under rheological state, the viscoelastic plastic model was used to study the stress evolution during rheological 2a, and Figures 13 and 14 were obtained.

It can be seen from Figure 13 that, with the advancement of time, the stress of coal at a point $5 \mathrm{~m}$ away from the coal has gradually decreased, and the stress curve in rheological state presents the form of power function curve. In addition, the stress evolution curve under the rheological state is divided into four stages. Firstly, during the 0.5 years of the rheological period, the lateral stress gradually decreased from 19.3 to $16.9 \mathrm{MPa}$, and the stress decreased by $2.4 \mathrm{MPa}$, with a change rate of $12.5 \%$. In the latter three stages, the flow stress showed a slow downward trend and gradually tended to be stable. Combined with the stress evolution in the dynamic loading stage, it can be concluded that the maximum stress change range is in the mining stage with a 0.5 -year rheological period.

After the coal enters the rheological state, the range of the plastic zone of the coal body gradually increases, and the distance between the peak stress of the coal mass and the coal wall (i.e. the range of the plastic zone) presents the power function curve development. The variation trend of the plastic zone during the two rheological years has been selected to make the evolution curve reach the peak abutment pressure, as shown in Figure 14. It can be seen from the figure that the plastic zone increases from 4.7 to $5.4 \mathrm{~m}$ during 0.5 rheological years, with a growth rate of $15 \%$. During the rheological period lasting one year, the range of plastic zone has increased to $0.25 \mathrm{~m}$ with a growth rate of $4.6 \%$. After one year of coal rheology, the range of the plastic zone has increased in a certain trend, but the growth rate has gradually decreased to zero during a certain period. It can be seen

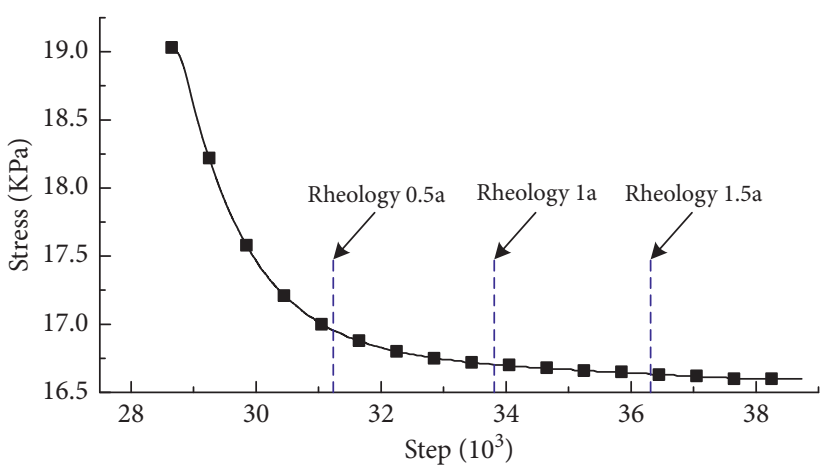

FIGURE 13: Support pressure evolution curve.

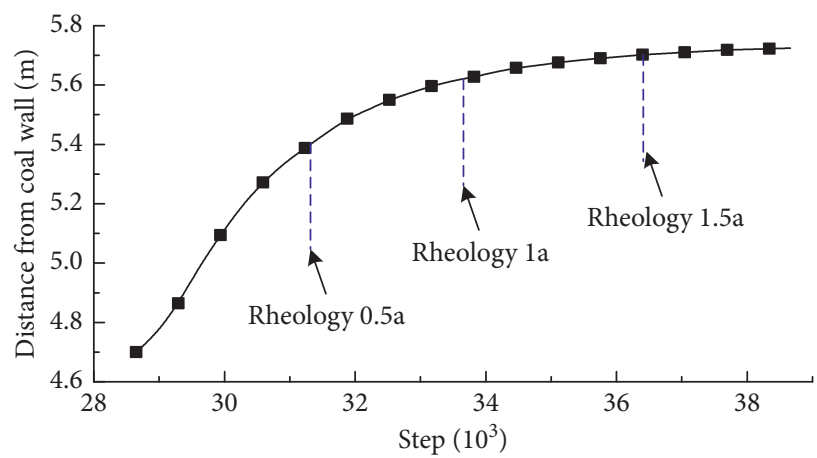

FiguRE 14: Support pressure peak evolution curve.

that, during the period of 0.5 years from the equilibrium of coal seam excavation to the rheological state, the range of plastic zone changes the most, which rationalizes the coal pillar setting and roadway excavation lagging behind the working face.

\section{Conclusions}

The stratum of the Yangjiacun coal mine is a composite key stratum structure. The fracture of the key stratum of coal seam mining forms a masonry beam, which leads to sliding instability and rotary deformation instability. The second subkey layer is suspended, and the working face continues to advance, with the strata collapse developing upwards and the lateral stress first increasing and then decreasing. The failure and instability of the key and overlying strata have produced different degrees of stress disturbance. The stress disturbance is more obvious near the coal wall, and the influence of stress disturbance gradually decreases with the distance to the coal wall increasing.

Under the action of dynamic loads, the pressure relief area is formed above the goaf of the coal seam, and the stress concentration is formed in the lateral coal body. The influence range of the stress curve gradually develops to the high and deep direction of the coal body. With the advance of the working face, the stress of measuring points at different depths from the coal wall first increases and then decreases, and the plastic zone range of the coal body is different in each stage but overall presents an increasing 
trend. The transformation curve is in the form of a power function curve.

After the overburden balance of coal seam excavation, the coal seam enters the rheological state under static load; the evolution law of the lateral abutment pressure increases with time; and the stress concentration coefficient decreases in the form of a parabola. Under the rheological action, the distance between the peak value of the lateral abutment pressure and the coal wall increases gradually, and the increasing rate decreases with the passage of time.

\section{Data Availability}

The data used to support the findings of this study are available from the corresponding author upon request.

\section{Conflicts of Interest}

The authors declare that there are no conflicts of interest regarding the publication of this paper.

\section{Acknowledgments}

This research was financially supported by the Engineering Laboratory of Deep Mine Rockburst Disaster Assessment Open Project (LMYK2020003), National Natural Science Foundation of China (51804179 and 51974173), Key Research and Development Plan of Shandong Province (2019GSF111024), Open Fund of State Key Laboratory of Water Resource Protection and Utilization in Coal Mining (SHJT-17-42.14), SDUST Research Fund (2018TDJH102), and Shandong Province's Taishan Scholar Talent Team Support Plan for Advantaged and Unique Discipline Areas.

\section{References}

[1] F. Russell and R. Guy, "Limitations and potential design risks when applying empirically derived coal pillar strength equations to real-life mine stability problems," International Journal of Mining Science and Technology, vol. 29, no. 1, pp. 17-25, 2019.

[2] A. G. Corkum and M. P. Board, "Numerical analysis of longwall mining layout for a Wyoming Trona mine," International Journal of Rock Mechanics and Mining Sciences, vol. 89, pp. 94-108, 2016.

[3] N. Sivakugan, S. Widisinghe, and V. Z. Wang, "Vertical stress determination within backfilled mine stopes," International Journal of Geomechanics, vol. 14, no. 5, pp. 1-5, 2014.

[4] C. Tian, X. Yang, H. Sun, Y. Liu, and Q. Hu, "Experimental study on the overburden movement and stress evolution in multi-seam mining with residual pillars," Energy Science \& Engineering, vol. 7, no. 6, pp. 3095-3110, 2019.

[5] J. Chai, W. L. Lei, W. G. Du et al., "Experimental study on distributed optical fiber sensing monitoring for ground surface deformation in extra-thick coal seam mining under ultrathick conglomerate," Optical Fiber Technology, vol. 53, pp. 1-12, 2019.

[6] H. Han, J. Xu, X. Wang, J. Xie, and Y. Xing, "Method to calculate working surface abutment pressure based on key strata theory," Advances in Civil Engineering, vol. 2019, Article ID 7678327, 20 pages, 2019.
[7] Q. Ye, G. Wang, Z. Z. Jia et al., "Similarity simulation of mining-crack-evolution characteristics of overburden strata in deep coal mining with large dip," Journal of Petroleum Science and Engineering, vol. 165, pp. 477-487, 2019.

[8] L. L. Yang, X. Yu, Y. Yang et al., "Physical simulation and theoretical evolution for ground fissures triggered by underground coal mining," PLoS One, vol. 13, no. 3, pp. 1-12, 2018.

[9] X. X. Kong, Q. S. Liu, Q. B. Zhang, Y. X. Wu, and J. Zhao, “A method to estimate the pressure arch formation above underground excavation in rock mass," Tunnelling and Underground Space Technology, vol. 71, pp. 382-390, 2018.

[10] S. Wang, X. Wu, Y. Zhao, and P. Hagan, "Mechanical performances of pressure arch in thick bedrock during shallow coal mining," Geofluids, vol. 2018, Article ID 2419659, 13 pages, 2018.

[11] F. Wu, X. Sun, J. Li et al., "Breaking features of loading key strata based on deep beam structure in shallow coal seam and its limited span-to-depth ratio," Bulgarian Chemical Communication, vol. 49, pp. 89-95, 2017.

[12] S. J. Song, X. G. Zhao, M. D. Gao et al., "Analysis on the influence of the average thickness of sandstone in overburden upon mining subsidence," in Proceedings of the 2015 International Symposium on Energy Science and Chemical Engineering, vol. 45, pp. 155-160, Guangzhou, China, December 2016.

[13] Y. Chen, F. G. Gong, and M. Zhao, "The study on the movement law of overlying strata in fully mechanized caving face under alluvium with huge thickness in deep mine," IOP Conference Series: Earth and Environmental Science, vol. 59, no. 1, 2017.

[14] P. F. Jiang, S. F. Dai, J. R. Liu et al., "Evolution of the comprehensive stress field and supporting measures for the roadway surrounding rock affected by strong mining in the deep and ultra-thick coal-seam," Coal Mining Technology, vol. 20, no. 6, 2015.

[15] Y. P. Fu, X. M. Song, P. W. Xing et al., "Study on simulation of caving and evolution law of roof strata of large mining height workface in shallow thick coal seam," Journal of China Coal Society, vol. 37, no. 3, 2012.

[16] Y. P. Liang, B. Li, and Q. L. Zou, "Movement type of the first subordinate key stratum and its influence on strata behavior in the fully mechanized face with large mining height," Arabian Journal of Geosciences, vol. 12, no. 2, 2019.

[17] K. W. Mills, O. Garratt, B. G. Blacka, L. C. Daigle, A. C. Rippon, and R. J. Walker, "Measurement of shear movements in the overburden strata ahead of longwall mining," International Journal of Mining Science and Technology, vol. 26, no. 1, pp. 97-102, 2016.

[18] Y. Yang, Y. Ma, C. Ji, T. Kang, and X. Guo, "Effect of mining thickness on overburden movement and underground pressure characteristics for extrathick coal seam by sublevel caving with high bottom cutting height," Advances in Civil Engineering, vol. 2018, pp. 1-15, Article ID 6871820, 2018.

[19] B. Yu, J. Zhao, T. Kuang, and X. Meng, "In situ investigations into overburden failures of a super-thick coal seam for longwall top coal caving," International Journal of Rock Mechanics and Mining Sciences, vol. 78, pp. 155-162, 2015.

[20] S. J. Chen and D. W. Yin, "Mechanical properties of rock-coal bi-material samples with different lithologies under uniaxial loading," Journal of Materials Research and Technology, vol. 10, pp. 322-338, 2021.

[21] A. Kidybinski and C. O. Babcock, "Stress distribution and rock fracture zones in the roof of longwall face in a coal mine," Rock Mechanics Felsmechanik M??canique des Roches, vol. 5, no. 1, pp. 1-19, 1973. 
[22] Y. Liu, W. Li, J. He, S. Liu, L. Cai, and G. Cheng, “Application of brillouin optical time domain reflectometry to dynamic monitoring of overburden deformation and failure caused by underground mining," International Journal of Rock Mechanics and Mining Sciences, vol. 106, pp. 133-143, 2018.

[23] B. Chen, S. C. Zhang, Y. Li et al., "Experimental study on water and sand inrush of mining cracks in loose layers with different clay contents," Bulletin of Engineering Geology and the Environment, vol. 80, no. 1, pp. 663-678, 2020.

[24] S. J. Chen and D. W. Yin, "Mechanical properties of oil shalecoal composite samples," International Journal of Rock Mechanics and Mining Sciences, vol. 123, Article ID 104120, 2019. 